\title{
An Overview of Dental Impression Disinfection Techniques- A Literature Review
}

\author{
Muhammad Asif Mushtaq ${ }^{1}$ \\ BDS \\ Muhammad Waseem Ullah Khan ${ }^{2}$ \\ BDS, FCPS
}

Dental impressions can act as vehicle for various types of micro-organisms E.g. Hepatitis B, C, HIV, Mycobacterium, Herpes simplex, Ebola, MERS-CoV etc. The most effective way to prevent their spread through dental impression is to make the impression sterile just after coming out of mouth. Various methods of impression disinfection have been described in literature having their own advantages, disadvantages and effects on impression material. In order to enhance the knowledge and improve the behavior of dental health care workers about impression disinfection, a structured literature review of the current disinfection techniques has been carried out. It will also provide knowledge about mechanism of action, concentration of usage along with commercial preparations available of different disinfectants. HOW TO CITE: Mushtaq MA, Khan MWU . An overview of dental impression disinfection techniquesa literature review. J Pak Dent Assoc 2018;27(4):207-12.

DOI: https://doi.org/10.25301/JPDA.274.207

Received: 27 July 2018, Accepted: 02 August 2018

\section{INTRODUCTION}

$\mathrm{T}$ he importance of cross-infection control cannot be overemphasized. Disinfection and sterilization methods are used to achieve disinfection and sterility of the medical and surgical instruments. In order to avoid the spread of pathogens from patients to patient, patient to health care personnel and health care personnel to patient, it is the duty of the health care policies makers to allocate the appropriate methods of cleaning, disinfection and sterilization for various surfaces and instruments. ${ }^{1}$ Cleaning is the removal of all foreign material (e.g. blood, saliva, debris) from objects while decontamination is the removal of pathogenic micro-organisms from objects. Disinfection is the process that eliminates many to all pathogenic microorganisms on inanimate objects except bacterial endospores. While sterilization is the complete elimination of all micro-organisms including spores. ${ }^{2}$ Disinfection can be divided into three categories according to their efficacy. High level disinfection involves bacterial spore inactivity along with other microbial forms. Intermediate level disinfection involves destruction of microorganisms like tubercle bacilli but not able to kill spore. Low level disinfection possesses narrow antimicrobial activity.

1. Resident, FCPS Department of Prosthodontics, and Punjab DentalHospital/ de'Montmorency College of dentistry.

2. Assistant Professor, Department of Prosthodontics, Punjab Dental Hospital /de'Montmorency College of dentistry.

Corresponding author: "Dr. Muhammad Asif Mushtaq" < dr.asif100@yahoo.com >
(Table 1). ${ }^{3,4,5}$ Dental impressions are categorized under semi-critical objects in dental practice and require high level disinfection or sterilization. ${ }^{6}$ Sterilization in an autoclave will compromise the dimensional accuracy of the impression hence it is not feasible. ${ }^{7}$ Until 1991, the recommended procedure for disinfection of impression was rinsing under running water with which only $40 \%$ of bacteria, viruses and fungi were removed and potential for transmission of microorganisms remains there. ${ }^{3,8,9}$ In recent times, a pre wash of the impression with running water is advocated first to cast off all particles, blood and saliva prior to active disinfection procedure. ${ }^{10}$ Disinfection of dental impression should be a routine procedure in the dental office and dental laboratory. By knowing all the methods and techniques, any dental personnel can make a better choice and get best results for impression disinfection. However, most of the dental professionals in private clinics, hospitals, dental schools and prosthetic laboratories are not following the required protocols for impression disinfection. ${ }^{11,12}$ Keeping in view the above findings, it is of utmost importance to raise the level of awareness in dental professionals involved in any process of handling, transportation, processing and storage of the dental impressions. Different techniques of impression disinfection and other methods of cross-infection control must be a part of undergraduate curriculum of dental universities and dental technician schools. The aim of this literature review is to generate an update on the various techniques of impression disinfection along with their mechanism of action and simple guidelines for their usage. 
Table 1: Levels of Disinfection. . $^{3,4,5}$

\begin{tabular}{|c|c|c|c|}
\hline $\begin{array}{l}\text { Type } \\
\text { Of } \\
\text { Disinfe } \\
\text { ction }\end{array}$ & Disinfectants & $\begin{array}{l}\text { Type of } \\
\text { impression } \\
\text { materials }\end{array}$ & $\begin{array}{l}\text { Time of } \\
\text { exposure }\end{array}$ \\
\hline \multirow{4}{*}{$\begin{array}{l}\text { High } \\
\text { level } \\
\text { disinfec } \\
\text { tion }\end{array}$} & \multirow[t]{4}{*}{ Glutaraldehyde } & $\begin{array}{l}\text { Irreversible } \\
\text { hydrocolloid }\end{array}$ & $10 \mathrm{~min}$ \\
\hline & & $\begin{array}{l}\text { Zinc-oxide } \\
\text { eugenol }\end{array}$ & $10 \mathrm{~min}$ \\
\hline & & $\begin{array}{l}\text { Polysulfide } \\
\text { Polyether }\end{array}$ & $10 \mathrm{~min}$ \\
\hline & & $\begin{array}{l}\text { Addition } \\
\text { silicon }\end{array}$ & $10 \mathrm{~min}$ \\
\hline \multirow{5}{*}{$\begin{array}{l}\text { Interme } \\
\text { diate } \\
\text { Level } \\
\text { Disinfe } \\
\text { ction }\end{array}$} & \multirow{5}{*}{$\begin{array}{l}\text { Sodium hypochlorite } \\
\text { Complex iodophors } \\
\text { Phenols } \\
\text { Chlorhexidine } \\
\text { Alcohols }\end{array}$} & $\begin{array}{l}\text { Irreversible } \\
\text { hydrocolloid }\end{array}$ & $10 \mathrm{~min}$ \\
\hline & & $\begin{array}{l}\text { Zinc-oxide } \\
\text { eugenol }\end{array}$ & $10 \mathrm{~min}$ \\
\hline & & $\begin{array}{l}\text { Polysulfide } \\
\text { Polyether }\end{array}$ & $10 \mathrm{~min}$ \\
\hline & & $\begin{array}{l}\text { Addition } \\
\text { silicon }\end{array}$ & $10 \mathrm{~min}$ \\
\hline & & $\begin{array}{l}\text { Impression } \\
\text { compound }\end{array}$ & $10 \mathrm{~min}$ \\
\hline $\begin{array}{l}\text { Low } \\
\text { Level } \\
\text { Disinfe } \\
\text { ction }\end{array}$ & $\begin{array}{l}\text { Quaternary } \\
\text { ammonium } \\
\text { compounds } \\
\text { Simple phenols } \\
\text { detergents }\end{array}$ & \multicolumn{2}{|c|}{$\begin{array}{l}\text { Not recommended for } \\
\text { impression disinfection }\end{array}$} \\
\hline
\end{tabular}

\section{Disinfection Techniques: \\ Disinfection solutions:}

The details are given in Table 2.4,13,14,15

Glutaraldehyde: It is a high level disinfectant and is available in neutral, alkaline and acidic forms. ${ }^{5}$ It is a broad spectrum chemical agent with fast killing capability. It is also called chemo sterilizer. If it is used in proper concentration and specialized equipment, it can destroy all types of micro-organisms including bacterial and fungal spores, tubercle bacilli and viruses. ${ }^{16}$ it is a colorless liquid with pungent odour. Although it is considered as the best disinfectant for cold sterilization of medical equipment, it also has many health hazards including irritation to skin, eyes and respiratory tract. It is a sensitizer of skin and respiratory tract, so special precautions are needed while using it e.g. wearing butyl or nitrile gloves, closed system for solution handling, exhaust ventilation of the places of handling and keeping the temperature of the solution low as it will reduce the airborne concentration of the solution. ${ }^{17}$

Sodium hypochlorite: It provides intermediate level
Table 2: Types of Disinfectants. ${ }^{4,13,14,15}$

\begin{tabular}{|c|c|c|c|c|}
\hline $\begin{array}{l}\text { Class of } \\
\text { disinfectant }\end{array}$ & $\begin{array}{l}\text { Type of } \\
\text { disinfectant }\end{array}$ & $\begin{array}{l}\text { Recommended } \\
\text { concentration }\end{array}$ & $\begin{array}{l}\text { Primary Mechanism } \\
\text { of action }\end{array}$ & $\begin{array}{l}\text { Commercial } \\
\text { preparations } \\
\text { available }\end{array}$ \\
\hline Glutaraldehyde & Non-oxidizing & $2 \%$ & $\begin{array}{l}\text { Alkylating agent for } \\
\text { proteins. Mainly } \\
\text { affects amines, } \\
\text { amides and } \\
\text { sulfhydryl groups }\end{array}$ & Cidex \\
\hline $\begin{array}{l}\text { Sodium } \\
\text { Hypochlorite }\end{array}$ & oxidizing & $\begin{array}{l}0.5 \% \\
\text { Or } \\
200-5000 \mathrm{PPM}\end{array}$ & $\begin{array}{l}\text { Disrupts cell } \\
\text { membrane transport } \\
\text { chain by causing } \\
\text { inhibition of } \\
\text { enzymes and } \\
\text { damage to DNA }\end{array}$ & $\begin{array}{l}\text { Clorox } \\
\text { Chloramine T } \\
\text { Purex }\end{array}$ \\
\hline Iodophors & oxidizing & $1-2 \%$ & $\begin{array}{l}\text { Proteins and } \\
\text { enzymes are } \\
\text { inactivated }\end{array}$ & $\begin{array}{l}\text { Betadine } \\
\text { Hy-Sine } \\
\text { Ioprep }\end{array}$ \\
\hline Alcohols & Non-oxidizing & $60-90 \%$ & $\begin{array}{l}\text { Cell membrane lipid } \\
\text { content is } \\
\text { solubilized and } \\
\text { proteins are } \\
\text { precipitated }\end{array}$ & Isopropyl alcohol \\
\hline Chlorhexidine & Non-oxidizing & $2-4 \%$ & $\begin{array}{l}\text { Intracellular } \\
\text { contents are } \\
\text { coagulated and cell } \\
\text { membrane is } \\
\text { damaged }\end{array}$ & Savlon \\
\hline Phenolic & Non-oxidizing & $1-3 \%$ & $\begin{array}{l}\text { Protoplasmic poison } \\
\text { causes damage to } \\
\text { cell membrane }\end{array}$ & $\begin{array}{l}\text { Lysol } \\
\text { Dettol } \\
\text { Hi-phene }\end{array}$ \\
\hline
\end{tabular}

disinfection and has a broad spectrum antimicrobial activity. It is very useful disinfectant with advantages including fast bactericidal activity, ease of use as it is soluble in water, relatively stable, nontoxic at use concentrations, low cost, non-staining, noninflammable and colorless. Disadvantages include mucous membrane irritation, less efficient in organic environment and corrosive effect on metals. ${ }^{13}$ According to one study, alginate impression disinfected with spray method using $1 \%$ Naocl did not show any severe dimensional changes or surface roughness of stone model that were fabricated from that impression. ${ }^{18}$ However, in another study impression disinfection by immersion method with $0.5 \% \mathrm{NaOCl}$ for 15 min exhibited small dimensional change. ${ }^{19}$

Iodophors: These halogens provide low to intermediate level disinfection. These are bactericidal, mycobactericial and virucidal. It is also fungicidal but requires more contact time. These are mainly used as antiseptics rather than disinfectants. These are not sporicidal and cause staining of fabrics. They are not flammable. They have irritating effect on mucous membrane. ${ }^{20,21}$ Organic material present on any surface can lead to neutralization of disinfectant capability of iodine. 
Hence, more frequent application of disinfectant is required for complete disinfection. ${ }^{3}$ According to one study, $30 \mathrm{~min}$ exposure to $0.1 \%$ povidine-iodine did not cause remarkable distortion of polysulfide and polysilixane impression material. ${ }^{5}$

Alcohols: These provide intermediate level disinfection and include isopropyl alcohol and ethyl alcohol. Isopropyl alcohol is normally used as antiseptic. Medical surfaces can also be disinfected with isopropyl alcohol. Ethyl alcohol is more potent in bactericidal than bacteriostatic activity. It is also tuberculocidal, fungicidal and virucidal for enveloped viruses as well. ${ }^{14,20,22,23}$ Alcohols are contraindicated for impression disinfection because they can cause surface changes of impressions. ${ }^{3}$ They are also not suitable for disinfection of denture bases consisting of non-cross linked resins. ${ }^{24}$

Phenols: Complex phenols are classified as intermediate level disinfectants. These are also known as protoplasmic poisons. At low concentration, they cause lysis of rapidly growing e.coli, staphylococci and streptococci. They possess antifungal and antiviral properties as well. ${ }^{23}$ These are commonly used in mouthwashes, scrub soaps and surface disinfectants. Ideally not recommended for impression disinfection as simple phenols are low level disinfectants. They are incompatible with latex, acrylic, rubber and cause acute toxicity as well.., 4

Chlorhexidine: It is an intermediate level disinfectant and antiseptic. It has broad spectrum of activity and also used as preservative .It is commonly used in hand washes and oral products. It is bactericidal, virucidal and mycobacteriostatic. Its activity declines in the presence of organic matter because its activity depends on specific $\mathrm{pH} .{ }^{23}$ $2 \%$ chlorhexidine has shown activity against s.aureus,e.coli,b.surbititis, but no antifungal activity was seen in agar diffusion test at low concentration. $0.2 \%$ chlorhexidine disinfectant solution can be used as water substitute in alginate mixing. Impression can also be immersed in chlorhexidine solution and it causes effective disinfection. ${ }^{25}$ According to one study, $1.0 \mathrm{~g} / \mathrm{L}$ chlorhexidine solution can be used to produce self-disinfecting alginate impression material for clinical use. In this way, it has shown antimicrobial activity and did not cause any changes in dimensional accuracy, flow ability and setting time of irreversible hydrocolloid impression material. ${ }^{26,27}$

Ozonated water: Ozone is an inorganic gaseous molecule. Its chemical formula is $\mathrm{O}_{3}$.It is less stable than $\mathrm{O}_{2}$ in lower atmosphere. ${ }^{3}$ It has antimicrobial, antihypoxic, analgesic and immunostimulatory activities. ${ }^{28}$ It is used for disinfection of water lines, oral cavity and dentures. It is also used as prophylactic agent before etching for the placement of restorations. ${ }^{29}$ Ozonated water can also be used as impression disinfectant. According to one study, aqueous ozone is more biocompatible than other disinfectant solutions e.g. chlorhexidine, $\mathrm{NaOCl}, \mathrm{H}_{2} \mathrm{O}_{2}$. Ozonated water can reduce the number of microorganisms on the surface of irreversible hydrocolloid impression materials and by increasing time of immersion more effective disinfection can be achieved..$^{28}$

\section{Other methods:}

Microwave irradiation: Microwaves cause disruption of cell membrane integrity and cell metabolism which ultimately leads to microbial death. ${ }^{3}$ Microwaves are simple to use, low in cost and provide good disinfection. Dentures are being disinfected with microwaves and are found better disinfected than Naocl. Microwaves can be used as an effective tool for impression disinfection. Polyvinyl siloxane impression materials were disinfected with microwaves with no changes in physical properties of impression material. ${ }^{30}$

Cast disinfection: Microorganisms have been recovered from dental cast as well. These dental casts can be a medium of cross infection between patients and dental health care workers. Therefore, dental casts should also be disinfected. ${ }^{7}$ The American Dental Association recommends various methods for cast disinfection. These include use of disinfectant spray, immersion in disinfectant solution, and incorporation of disinfectant in stone at the time of mixing. ${ }^{31}$ Immersion in $0.525 \% \mathrm{NaOCl}$ did not cause any changes in dimensional accuracy, surface detail quality and compressive strength. ${ }^{32}$ Microwave irradiation can also be used for cast disinfection. Dental cast can also be sterilized. ${ }^{3}$

Sterilization of impression: Various methods are available for sterilization of impressions e.g. exposure to UV light, steam autoclave, ethylene oxide gas autoclave, and radiofrequency flow discharge etc. ${ }^{3}$

\section{DISCUSSION}

Cross-infection control is of prime importance in dental practice but impression disinfection is still a widely neglected aspect. The proper criteria for impression disinfection involves:

1) The most suitable method (spray or immersion).

2) Appropriate application (time of contact).

3) Periodic check for efficacy. ${ }^{33}$

The factors to be considered for any disinfection protocol for dental impression are effectiveness, chemical stability and efficacy of the disinfectant solution. The disinfection procedure should not alter the dimensions and surface details 
of the impression and resultant cast. ${ }^{32,34}$ It has been proven that the most effective method of reducing the burden of micro-organisms from impression surface is chemical disinfection. Spray disinfection and immersion disinfection are the two methods of impression disinfection. However, immersion is the most reliable method because all surfaces of impression and tray come in contact with disinfectant solution. But immersion is not the method of choice for hydrocolloids material as they are extremely hydrophilic. ${ }^{3,34}$

In 1996, the American Dental Association council on dental materials endorsed immersion for polysulphide and addition silicone impression material whereas spraying with chlorine compound was advocated for disinfection of polyether impression material for 2-3 min. ${ }^{35} \mathrm{UV}$ rays can be used for disinfection of water supplies, laboratory equipment, dental headpieces, dental impression and implants. In one study, while comparing UV rays disinfection with Glutaraldehyde and $\mathrm{NaOCl}$, UV rays exhibited maximum efficacy. ${ }^{36}$

The factors affecting the efficacy of $\mathrm{NaOCl}$ include concentration and life of solution, $\mathrm{pH}$, temperature and contact time with the impression surface. According to Fahimeh et al, the compatibility of disinfectant solution with impression material should be assessed prior to disinfection procedure. Any compatible disinfectant solution should not cause any alteration on the surface detail reproduction. ${ }^{37}$

Although some chemical disinfectants cause dimensional changes in impression surface, these changes are not expected to alter the clinical performance. This is why, chemical disinfection is considered the most harmless form of impression disinfecion. $2 \%$ gluteraldehyde had exhibited more dimensional changes than $5.25 \% \mathrm{Naocl}$ in immersion disinfection procedure. ${ }^{38}$

The American Dental Association's revised guidelines recommend chemical agents that are virucidal, bactericidal and sporicidal. These chemical agents are chlorine compounds, phenols, iodophors, formaldehyde and gluteraldehyde. Immersion in $\mathrm{NaOCl}$ at concentration of $1: 10(0.525 \%)$ is advised for 10 minutes. Samra and Neiman investigated the effects of gluteraldehyde, phenol, iodophors and chlorine compound immersion disinfection procedure on set stone cast. The results of this study showed that a $0.525 \%$ Naocl least affected the cast with regard to compressive strength, surface changes, surface hardness and chemical reactivity. ${ }^{32}$

The Japan Prosthodontic Society has recommended the alginate impression in either $0.1-1 \%$ Naocl solution for 15-30 min or $2-3.5 \%$ gluteraldehyde solution for $30-60$ minutes. But immersion in gluteraldehyde for more than 30 min has shown dimensional changes and altered surface quality of the resultant cast. ${ }^{19}$
Ethylene oxide gas autoclaving has shown significant structural changes of heavy and light body addition silicone impression material. Sterilization of dental stone cast has shown improved mechanical properties but decreased compressive strength. Addition or condensation silicone impression materials can be sterilized in steam autoclave without remarkable changes in dimensional accuracy. ${ }^{3}$

\section{CONCLUSIONS}

1) Cross infection control is very important aspect of patient safety

2) Impression disinfection can prevent spread of infection from dental clinic to dental laboratory technician, patients and dental auxiliaries

3) It is the responsibility of the dentist to make appropriate choice of disinfection method for different impression materials.

\section{CONFLICT OF INTEREST}

None declared.

\section{REFERENCES}

1. Rutala WA, Weber DJ. Disinfection and Sterilization in Health Care Facilities: What Clinicians Need to Know? Clin Infect Dis; 2004; 39(5):702-9.

https://doi.org/10.1086/423182

2. Rutala WA, Weber DJ. Infection control: the role of disinfection and sterilization. J Hosp Infect; 1999; 43:S43-S55. https://doi.org/10.1016/S0195-6701(99)90065-8

3. Chidambaranathan AS, Balasubramanium M. Comprehensive Review and Comparison of the Disinfection Techniques Currently Available in the Literature. J Prosthodont. 2017:12597.

4. Hemalatha, R., \& Ganapathy, D. Disinfection of dental impressionA current overview. Int J Pharm Sci Res;2016;7(8):661-64.

5. Merchant VA, Kay McNeight M, James Ciborowski C, Molinari JA. Preliminary investigation of a method for disinfection of dental impressions. J. Prosthet. Dent; 1984;52(6):877-9.

https://doi.org/10.1016/S0022-3913(84)80024-4

6. Rutala WA. APIC guideline for selection and use of disinfectants. Am J Infect Control; 1996;24(4):313-42.

https://doi.org/10.1016/S0196-6553(96)90066-8

7. Leung RL, Schonfeld SE. Gypsum casts as a potential source of microbial cross-contamination. J. Prosthet. Dent; 1983;49(2):210-1. https://doi.org/10.1016/0022-3913(83)90503-6

8. Badrian H, Ghasemi E, Khalighinejad N, Hosseini N. The Effect of Three Different Disinfection Materials on Alginate Impression by 
Spray Method. ISRN Dent; 2012:1-5. https://doi.org/10.5402/2012/695151

9. Rentzia A, Coleman DC, O'Donnell MJ, Dowling AH, O'Sullivan M. Disinfection procedures: their efficacy and effect on dimensional accuracy and surface quality of an irreversible hydrocolloid impression material. J Dent; 2011;39(2):133-40.

https://doi.org/10.1016/j.jdent.2010.11.003

10. Correia-Sousa J, Tabaio AM, Silva A, Pereira T, Sampaio-Maia $\mathrm{B}$, Vasconcelos $\mathrm{M}$. The effect of water and sodium hypochlorite disinfection on alginate impressions. Rev Port Estomatol Cir Maxilofac; $2013 ; 54(1): 8-12$.

11. Ferreira FM, Novais VR, Júnior PC, Soares CJ, Neto AJ. Evaluation of knowledge about disinfection of dental impressions in several dental schools. Rev Odontol Bras Centra2011;19(51)285-89.

12. Yüzbasioglu E, Saraç D, Canbaz S, Saraç YS, Cengiz S. A survey of cross-infection control procedures: knowledge and attitudes of Turkish dentists. J Appl Oral Sci. 2009;17(6):565-9.

https://doi.org/10.1590/S1678-77572009000600005

13. Fukuzaki S. Mechanisms of actions of sodium hypochlorite in cleaning and disinfection processes. Biocontrol Sci. 2006; 11(4):147-57. https://doi.org/10.4265/bio.11.147

14. Martínez JE. Mode of Action and Development of Resistance to Disinfectants, Part 2. Bioprocess Int. 2005;3(8):32-8.

15. 8.0 Disinfection and Sterilization | Environmental Health and Safety. [Online] Available at: https://ehs.research.uiowa.edu/80disinfection-and-sterilization [Accessed 24 Jun. 2018].

16. Gorman SP, SCOTT EM, Russell AD. Antimicrobial activity, uses and mechanism of action of gluteraldehyde. J. Appl. Microbiol. 1980; 48(2):161-90

17. Takigawa T, Endo Y. Effects of glutaraldehyde exposure on human health. J Occup Health. 2006;48(2):75-87.

https://doi.org/10.1539/joh.48.75

18. Guiraldo RD, Borsato TT, Berger SB, Lopes MB, Gonini-Jr A, Sinhoreti MA. Surface detail reproduction and dimensional accuracy of stone models: influence of disinfectant solutions and alginate impression materials. Braz. Dent. J. 2012;23(4):417-21. https://doi.org/10.1590/S0103-64402012000400018

19. Hiraguchi H, Kaketani M, Hirose H, Yoneyama T. Effect of immersion disinfection of alginate impressions in sodium hypochlorite solution on the dimensional changes of stone models. Dent Mater J. 2012; 31(2):280-6.

https://doi.org/10.4012/dmj.2010-201

20. utala WA, Weber DJ. Disinfection, sterilization, and antisepsis: An overview. Am J Infect Control. 2016;44(5):e1-6. https://doi.org/10.1016/j.ajic.2015.10.038

21. Lawrence CA, Carpenter CM, Naylor-Foote AW. Iodophors as disinfectants. J Am Pharm Assoc. 1957;46(8):500-5. https://doi.org/10.1002/jps.3030460813

22. Morton HE. The relationship of concentration and germicidal efficiency of ethyl alcohol. Ann N Y Acad Sci.1950;53(1):191-6. https://doi.org/10.1111/j.1749-6632.1950.tb31944.x

23. McDonnell G, Russell AD. Antiseptics and disinfectants: activity, action, and resistance. Clin. Microbiol. Rev. 2001;14(1):147-79.

24. Asad T, Watkinson AC, Huggett R. The effect of disinfection procedures on flexural properties of denture base acrylic resins. J Prosthet Dent. 1992;68(1):191-5.

https://doi.org/10.1016/0022-3913(92)90303-R

25. Touyz LZ, Rosen M. Disinfection of alginate impression material using disinfectants as mixing and soak solutions. J Dent. 1991; 19(4):255-7.

https://doi.org/10.1016/0300-5712(91)90133-J

26. Wang J, Wan Q, Chao Y, Chen Y. A self-disinfecting irreversible hydrocolloid impression material mixed with chlorhexidine solution. Angle Orthod.2007;77(5):894-900.

https://doi.org/10.2319/070606-277

27. Kollu S, Hegde V, Pentapati KC. Efficacy of Chlorhexidine in Reduction of Microbial Contamination in Commercially Available Alginate materials-in-Vitro Study. Global J Med Res. 2013;13(2): 19-24.

28. Savabi O, Nejatidanesh F, Bagheri KP, Karimi L, Savabi G. Prevention of cross-contamination risk by disinfection of irreversible hydrocolloid impression materials with ozonated water. Int J Prev Med. 2018; 9:37.

https://doi.org/10.4103/ijpvm.IJPVM_143_16

29. Azarpazhooh A, Limeback H. The application of ozone in dentistry: a systematic review of literature. J Dent. 2008; 36(2):104-16. https://doi.org/10.1016/j.jdent.2007.11.008

30. Choi YR, Kim KN, Kim KM. The disinfection of impression materials by using microwave irradiation and hydrogen peroxide. $\mathrm{J}$ Prosthet Dent. 2014;112(4):981-7.

https://doi.org/10.1016/j.prosdent.2013.12.017

31. Infection control recommendations for the dental office and the dental laboratory. J Am Dent Assoc; 1996;127(5):672-80. https://doi.org/10.14219/jada.archive.1996.0280

32. Abdullah MA. Surface detail, compressive strength, and dimensional accuracy of gypsum casts after repeated immersion in hypochlorite solution. J Prosth Dent. 2006; 95(6):462-8.

https://doi.org/10.1016/j.prosdent.2006.03.019

33. Maillard JY, McDonnell G. Selection and use of disinfectants. In Prac. 2012; 34(5):292-9.

https://doi.org/10.1136/inp.e2741

34. Lepe X, Johnson GH. Accuracy of polyether and addition silicone 
after long-term immersion disinfection. J Prosthet Dent. 1997; 78(3): 245-9.

https://doi.org/10.1016/S0022-3913(97)70021-0

35. Samra RK, Bhide SV. Efficacy of different disinfectant systems on alginate and addition silicone impression materials of Indian and international origin: a comparative evaluation. J Indian Prosthodont Soc. 2010;10(3):182-9.

https://doi.org/10.1007/s13191-010-0040-y

36. Shambhu HS, Gujjari AK. A study on the effect on surface detail reproduction of alginate impressions disinfected with sodium hypochlorite and ultraviolet light-An in Vitro study. J Indian Prosthodont Soc. 2010;10(1):41-7.

https://doi.org/10.1007/s13191-010-0005-1
37. Rad FH, Ghaffari T, Safavi SH. In vitro evaluation of dimensional stability of alginate impressions after disinfection by spray and immersion methods. J Dent Res Dent Clin Dent Prospects. 2010; 4(4):130-35.

38. Kotsiomiti E, Tzialla A, Hatjivasiliou K. Accuracy and stability of impression materials subjected to chemical disinfection-a literature review. J Oral Rehabil.2008;35(4):291-9.

https://doi.org/10.1111/j.1365-2842.2007.01771.x 